\title{
Facile Synthesis of 5-Carboxylate Substituted Piperazin-2-ones as Peptidomimetic Agents
}

\author{
Yong Jun Chung, Youn-Chul Kim, and Ho-Jin Park

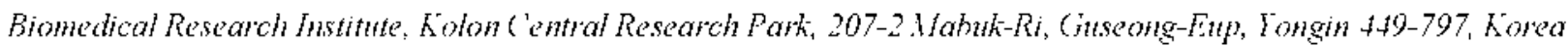 \\ Received May'29, 2002
}

Key Words : Peptidomimetic, Anti-angiongenic, Piperarin-2-one. Tandem reaction

Recent progress in conformationally-restricted peptidomimetics with biologically active molecules points toward the need for progress with new and diverse small-molecular scaffolds possessing appreciated substituents at various positions.' The introduction of piperazinones has been actively pursued in recent years due to the importance of this class of compound in this field. Piperazinones are widely applicable to the development of peptidomimetic drugs in medicinal chemistry: including enzyme inhibitors. peptide secondary structure mimetics and combinatorial libraries. A literature surey on the preparation of piperazinones shows that a variety of methods have been reported based on cyclization of functionalized etlyy lenediamines with $\alpha$-haloacetic acid derivatives ${ }^{2 a-1 \mathrm{l}}$ or organoboronic acids, ${ }^{\text {-e }}$ intramolecular cyclization of peptidic analogous ${ }^{3 \mathrm{n}-\mathrm{c}}$ and condensation of $\mathrm{A}$ (chloroethy l)gly cinate with amines. ${ }^{4}$ Nevertheless. there are relatively few synthetic methods for the preparation of piperazinones by tandem cyclization with amunes. ${ }^{2,4.5}$

In the present paper, we report the reaction of sulfonamide-protected serine derivative 2 with mesyl chloride. followed by the addition of a primary amine. which leads to the formation of piperazin-2-ones 3 in one pot. This reaction proceeded through tandem $\beta$-elimination of the mesylate- activated hydroxyl group, conjugate addition of the enone with amines and $\mathrm{g}$ clization under mild condition.

A synthetic route for new piperazin-2-ones 3 is outlined in Scheme 1. The synthesis was carried out using t-nitrobenzenesulfonyl-protected serine methyl ester 1 as the starting material. Compound 1 was readily prepared from serine methyl ester and 4-uitrobenzenesulfony l chloride. a versatile protecting group of amines. ${ }^{6}$ Compound 1 was alkylated efficiently under the conventional condition $\left(\mathrm{K}_{2} \mathrm{CO}_{3}, \mathrm{DMF}\right.$. rt) to give methyl 2-lethosy carbory lmethyl-(+-nitro-benzenesulfony 1)-amino]-3-hydroxy-propionate 2 in good yield ( 86 $\%$ ). The hydroxyl group of compound 2 was activated with mesyl chloride, followed by the addition of primary anines smoothly converted to the piperazin-2-ones 3 in one pot.

We expected that the reactions might undergo a tandem direct $\mathrm{S}_{x} 2$ displacement of actixated hydroxyl group with primary amines and cyclization of the ethyl ester with the resulting secondary amines. However. with careful scrutiny of the reaction. we found that the reaction took place exclusively through conjugate addition of the enone 4 rather than the intermediate of $\mathrm{S} \times 2$ displacement (Scheme 2).

The dehydration of $\beta$-hydroxyamino acid derivatives is well known. and we could detect the enone compound 4 in<smiles>COC(=O)C(CO)NS(=O)(=O)c1ccc([N+](=O)[O-])cc1</smiles>

1 a<smiles>CCOC(=O)CN(C(CO)C(=O)OC)S(=O)(=O)c1ccc([N+](=O)[O-])cc1</smiles>

2<smiles>[R]N1CC(C(=O)OC)N(S(=O)(=O)c2ccc([N+](=O)[O-])cc2)CC1=O</smiles>

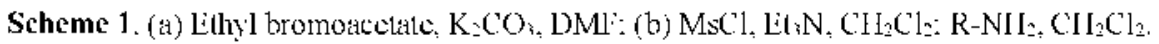<smiles>[R]NCC(C(=O)OC)N(CC(=O)OCC)S(=O)(=O)c1ccc([N+](=O)[O-])cc1</smiles>

Scheme 2 
Table 1. Landem ayclization ration of the compound 2 toward piperazin-2-ones 3

\begin{tabular}{|c|c|c|c|}
\hline Entry & Amine" & Product & Yicld $\left(0_{0}\right)^{\prime}$ \\
\hline 1 & Ammonium ḥִ droxide & $3 a\left(R^{-} H\right)$ & 64 \\
\hline 2 & Methỵlamine & $\mathbf{3 b}\left(\mathrm{R}-\mathrm{CH}_{3}\right)$ & 72 \\
\hline 3 & Benzylamine & $3 c\left(\mathrm{R}-\mathrm{CH}_{2} \mathrm{Ph}\right)$ & 68 \\
\hline 4 & Allỵlaminc & $3 \mathrm{~d}\left(\mathrm{R}-\mathrm{CH}_{2} \mathrm{CH}^{-} \mathrm{CH}_{2}\right)$ & 69 \\
\hline 5 & Cyclopropylamint & $3 \mathbf{e}\left(\mathrm{R}-\mathrm{CH}\left(\mathrm{CH}_{2}\right)_{2}\right)$ & 74 \\
\hline 6 & Ethanolamine & $3 \mathbf{2}\left(\mathrm{R}-\mathrm{CH}_{2} \mathrm{CH}_{2} \mathrm{OH}\right)$ & 85 \\
\hline 7 & Glỵeine $t$-buțl ester $\mathrm{HCl}$ & $3 \mathrm{~g}\left(\mathrm{R}-\mathrm{CH}_{2} \mathrm{CO} / \mathrm{Bu}\right)$ & 89 \\
\hline 8 & Aniline & $3 \mathrm{~h}(\mathrm{R}-\mathrm{Ph})$ & 0 \\
\hline
\end{tabular}

"Amine was diluted with $\mathrm{CII}_{2} \mathrm{Cl}$ or dioxane (for aquenus amine), and added to the reaction mixture. "These isolated yields are not optimized.

TLC during the reaction. Compound + was isolated and claracterized by NMR experiments.

To explore the scope of the reaction. a series of piperazin2-ones differing only at the $\mathrm{R}$ amide position was prepared (Table 1). Most aliphatic primary amines afforded piperazin2-ones 3 in good yield under the standard reaction conditions. ${ }^{\ominus}$ even with aqueous amines. An amine containing reactive functionality, such as alcohol (entry 6). was well tolerate in the reaction condition. In the case of aniline (entry 8 ). the reaction resulted in the accumulation of only $\beta$ eliminated compound 4 . Because of poor mucleophilicity of aniline. the conjugate addition might not proceed in the reaction conditions. In our reaction. under the conjugate addition condition the cyclization of the intermediate 5 took place in tandem mode.

To the best of our knowledge, this could be the first example of a tandem $\beta$-elimination-conjugate addition-cyclization reaction to prepare piperazin-2-ones from hydroxylester compounds in one pot. The advantages of this method are really simple and give good overall yields for the preparation of piperazin-2-ones 3. Furthermore. the reaction is an efficient and convenient method for the preparation of piperazin-2-one analogous with stnictural diversity of Rgroups at the amide position due to the wide availability of amine components.

In conclusion. a facile synthesis of 5-carboxylate substituted piperazin-2-ones has been developed. Our strategy allows the introduction of a variety of substituents at the amide $\mathrm{N}$ position. Applications for the preparation of conformationally-restricted peptides and enzyme inhibitors. which exhibited anti-angiogenic activity. have been achieved and will be reported in due course.

\section{References and Notes}

1. (a) Gante. J. Angew. (hem. Int. Fd Fingl 1994. 33. 1699. (b) Hanessian. S.: MeNaughton-Smith. G.: Lombart. H.-G.: Lubell. W. D. Tefrahtedm 1997. 53. 12785) (c) Ripka. A. S.: Rich. D. H. Curf Opin. Chem Biol. 1998, 2, 441.

2. (a) Dinsmorc, C. J.: 7.artman, C. B. Tetrahedron Lett. 2000, H.
6309 and references cited therein. (b) froelich. O.: Cossant. F.: Bonin. M.: (Quirion. J.C.: Husson. H.-P. Heterocycles 1999. 51. 2065. (o) Golebionshi. A.: Kloplenstein. S. K.: Shiso. X.: Chen. d. J.: Colson, A.O.: Crried, A. J.: Russell. A. F. Org. Lkff 2000, 2. 2615. (d) Dinsmore, C. I.: Bergmatı. I. M.: Wei, D. D.: 7artmatn, C. B.: Daride, J. P.: Greenberg. I. B.: I.iu. D.: ONeill. T. J.: Gibbs. J. B.: Koblan. K. S.: Kohl. N. E.: Lobell. K. B.: Chen. 1.-W: McLomghlin. D. A.: Olah. I. V.: Graham. S. L.: Hartman. G. D.: Williams. I. M. Bioory Hed Chem. Lett 2001. 11. 537. (e) Petasis, N. A.; Patel. 7. D. Tetruhedrom Left. 2000, H. 9607.

3. (a) DiMaio, J.: Belleau. B. J. Chem. Soc. Ierhim Trems. I 1989. 1687. (b) Kogan. T. P.: Rawson, T. F. Thtwhedron Lett. 1942. 3.3. 7089. (c) Balt. A. R.: Kendrick. D. A.: Mathews. E.: Rooker. D. P.: Ryder. H.: Semple. G.: Szelke. M. Bioorg . Wed Chom Lett 1994. 4. 867. (d) Mickelson. I. W.: Jacobsen. E. T. Tetrohtedron: Assmmetin 1995. 6. 19. (c) Kolter. T.: Dahl. C.: Giantnis, A. Liebigs Am 1995. 625. (f) Prahl. A.: Weirzba. T.: Winklewski. P. Musial. P.: Juzia. W.: I ammek, B. Potish J. Chem. 1997, 71. 929. (g) Uchida. H.: Kalo. l': Achiwa. K. (hem. Pham. Bull. 1997. 45. 1228. (h) Shreder. K.: Zhang. L.: Goxdman. M. Tetrahedron lett, 1998. 39. 221, (i) Mohamed. N.: Bhalt. U.: Just. G. Tetrohedhom Lett. 1998, 39, 821.3. (i) Shreder. K.: 7hang. I.: Glesson. J.-P.: Fricsson, I. A.: Yalamoori, V. V. Goodman, M. J. Comb. Chem. 1999. 1. 38.3. (k) Hansen. T. K.: Schlienger, N.; I Iansen. B. S.: Andersen. P, H.: Bryce. M. R. Tetrahedron Lett. 1999. to. 3651. (1) Kung. P.-P?: Swayze. E. Tetrahedron Lett. 1999. to. 5651. (m) Patiño-Molina. R.: Herranz. R.: Saraia-López. M. T.: González-Muñiz. R. Tetrahedrom 1999. 55. 15001. (n) Ilulme. C.: Ma, I..: Kumar. N. V.: Krolikouski. P. II.: Allen, A. C.: I.abaudinice. R. Tetrahedim Lett 2000, 41. 1509. (o) Berst, F. Holmes. A. B.: Ladlow: M.: Muпay. P. J. Tetrohedryn Lett. 2000. 41.6649. (p) Rü̈bsam. F.: Mazitschek. R.: Giannis. A. Tetrahedron 2000. 56. 8481. (q) Kim. H.-O.: Nakanishi. H.: Lee. M. S.: Kalln. M. Org. Letl. 2000, 2.301

4. Struve. G. F... Gazzola. C.: Kenyon. G. I. J. Org. Chm. 1977, 42. 40.35 .

5. Goll. D. A. Tetrahedom Lett. 1998. 39. 1473.

6. Fukuyama. T.: Jow. C.-K.: Cheung. M. Tetrahedron Lett, 1995. 36.6373 .

7. (a) IJumphery, I. M.: Chamberlin, A. R. Chem. Rov 1997, 97, 224.3. (b) Schmidt. IJ. I icberknecht. A.: Wild. I. Symhesis 1998. 159

8. 4: yellowish crystal. 'H NMR (CDCl $\left.{ }_{2 .} 400 \mathrm{MHz}\right) \delta 1.26(\mathrm{~L} . J-7.0$ Hz. 3H). 3.70 (s. $3 \mathrm{H}) .4 .18$ (c. $2 \mathrm{H}$ ). $4.3 \mathrm{l}$ (s. $2 \mathrm{H}$ ). 6.19) (s. 1H). 6.55 (s. $1 \mathrm{H}) .8 .03(\mathrm{~d} . J-8.8 \mathrm{H} \angle .2 \mathrm{H}) .8 .34(\mathrm{~d} . J-8.8 \mathrm{~Hz} .2 \mathrm{H}):{ }^{13} \mathrm{C}$ NMR (CDCl $3.100 \mathrm{MH}$ ) $\delta$ 1.3.9. 50.4. 52.6. 61.6. 12.9. 128.9 . 1.32.1. 1.34.7, 144.9, 150.1. 163.2, 168.3: MS (m:c) $37.3\left(\mathrm{M}^{\prime}+1\right)$. $313,299,249.186,122,76,54 ; \mathrm{m}, \mathrm{p} .100-101^{\circ} \mathrm{C}$.

9. Representative procedure: 3a: To a solution of $2(0.40$ g. 1.0 mmmol) and $\mathrm{Et}_{3} \mathrm{~N}(0.47 \mathrm{~mL} .3 .4 \mathrm{mmol})$ in $15 \mathrm{~mL} \mathrm{of} \mathrm{CH}_{2} \mathrm{Cl}_{2}$ at 0 "C was added dropwise methanesulfonyl chloride $(0.10 \mathrm{~mL} .1 .3$ mmol). After stirring for 3 h at it. ammonium hrdroxide $\left(28^{\circ}\right.$ o. $0.39 \mathrm{mI}$. . $3.0 \mathrm{mmol}$ ) solution diluted with $10 \mathrm{mI}$, of dioxanc was added dropwise at $0^{\circ} \mathrm{C}$. After stiring tor $16 \mathrm{~h}$ at it. $\mathrm{H}_{2} \mathrm{O}(20 \mathrm{~mL}$.) was added. and the mixture was partitioned. The oreanic layer was dried over anlydrous $\mathrm{MgSO}$. Fillered. and concentrated in vacho. Recrystallization from ethyl acetate hexane provided piperacinone 3a as a white solid $\left(0.22\right.$ g. $64^{\circ}$ o vield). 'II NMR (CDCl $-\mathrm{CD}_{3} \mathrm{OD}$ $400 \mathrm{MH}$ ) $\delta .3 .61$ (s, 3I ), 3.76 (br's. $2 \mathrm{IJ}$ ), 3.89 (d, $J$ - $16.8 \mathrm{HJ}$.

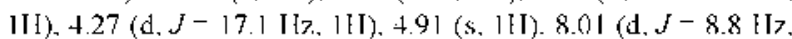
$2 \mathrm{H}) .8 .40(\mathrm{~d} .7-8.5 \mathrm{~Hz} .2 \mathrm{H}):{ }^{13} \mathrm{C}$ NMR (CDCl $\cdot \mathrm{CD}_{3} \mathrm{OD} .100$ MHz) $\delta 43.6 .45 .7 .53 .2 .53 .6 .124 .5 .128 .9 .143 .6 .150 .5 .165 .8$. 168.7: MS (nle) 344 (M-। 1). 284. 186. 157. 122.97. 76.69: m.p. $184^{\circ} \mathrm{C}$. 